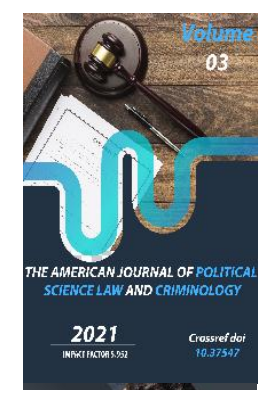

\title{
Procedure Of Land Seizure For State And Public Needs As An Example Of Developed Countries
}

\author{
Ulfat Shonazarov Ibrogim Ugli \\ Lecturer Of The Department Of State Law Disciplines Of Specialized Branch Of Tashkent State \\ University Of Law, Uzbekistan
}

Journal Website:

http://theamericanjour

nals.com/index.php/taj

pslc

Copyright: Original

content from this work

may be used under the

terms of the creative

commons attributes

4.0 licence.

\section{ABSTRACT}

In this article, the author carried out a general analysis of land seizure for state and public needs on the basis of the legislation of national and developed countries. The author also touched upon what is meant by the state and public needs, the compensation of the owner for the property located on the seized land plot and the issues of property valuation. In addition, the article also included proposals on the development of legislation regulating this relationship.

\section{KEYWORDS}

Land plot, state need, public need, seizure, compensation, appraisal.

\section{INTRODUCTION}

At present, in practice, we can witness cases when private property rights to residential, building and structures, as well as commercial and service facilities, which in many cases belong to citizens, are to be abolished in connection with the seizure of land on which they are located, for public and public needs. In this process, it is important to protect the property rights and interests of citizens. And for this, step-by-step changes are being introduced into our legislation.
It should be noted that the legislation, which was in force during the former Union, did not provide Real guarantees for the protection of property rights of citizens in such cases. In particular, their right to residential property and land area was abolished by the relevant decisions of the Executive Councils Committees of public deputies of the region, citizens could apply to the court no for determining the justification and expediency of these decisions, as well as neither for the 
amount of compensation established by the special commission.

The reforms carried out after independence and the non-legal acts adopted have literally returned to citizens this right, which has been restricted for years.

The seizure of the land plot for the needs of the state and the public is a must in the legislation of many states. Therefore, the abolition of property rights in view of the needs of the state and the public, in some foreign countries is called "compulsory seizure of property".

Compulsory seizure of property is the seizure of property by the government on the basis of involuntary measures, without the consent of the owner or tenant, in view of public needs[1].

In Australian law, "the concept of compulsory seizure is described as follows: "seizure by a state body or institute for the purpose of carrying out public works (construction) of a privately owned land or property is recognized as compulsory seizure[2]."

The fact that such seizure of property has the character of involuntary at first glance seems to be confiscated. However, the different aspect of confiscation is that first of all the confiscation is considered one of these punishments. Secondly, when the property is confiscated, compensation is not paid to it. The fact is that the compulsory seizure of property is a measure of punishment, but also a measure arising from the needs of the state and the public, and also when the property is forcibly seized, the owner is obliged to pay compensation.
In this case, it should be specially pointed out that the state body does not pay direct attention to the seizure of property located on the land plot, unlike its decision on the abolition of the right to property, the confiscation of the right to property, the acquisition of cultural property stored by the owners and other similar methods.

Compulsory seizure of property is of decisive importance in the development of the state. Since by this way, the state will modernize its outdated infrastructure, including modern urban development. Also, countries with a sharply growing population, with the aim of providing their population with housing, will also forcibly take away housing from the owners and restore high-rise modern multiapartment houses.

In the national constitutions and laws of almost all states, the concept of compulsory seizure of property is used together with the expression "for public use", "for public purposes", "in view of the interests of the state and the public". In some jurisdictions, if the meaning of these expressions is clearly stated in the law, in others, either ambiguities are allowed, or in general the definition of these concepts is not mentioned.

In the commentary to the Civil Code of the Republic of Uzbekistan, the concept of State and public needs is described as follows: " the possible needs that are essential for the implementation of state functions and, perhaps, can only be satisfied by the seizure of land plots (construction of roads, power lines, communication systems, transmission means state needs[3]". 
As well as Regulation.gov.uz - the law "on procedures for withdrawal of land parcels for compensation evasion for public needs[5]" uploaded by the Ministry of Justice of the Republic of Uzbekistan on the projects discussion platform of normative-legal documents is expected to be a special normative-legal document regulating these social relations.

In Article 5 of the law of draft, there are cases on which the seizure of land parcels for the purposes of compensation evasion for public needs is justified, in the following case, the seizure of land for the purposes of state and public needs is allowed:

* provision of lands for defense and state security, the needs of protected natural areas, the organization of Special Economic Zones and their functioning;

* Fulfillment of obligations arising from international agreements of the Republic of Uzbekistan;

* Detection and extraction of deposits of minerals (except for deposits of common minerals);

* Construction (reconstruction) of motor and railway roads, airports, airfields, Aeronautics and aviation centers, railway facilities, bridges, metropolitans, tunnels, energy and communication system engineering facilities and networks, space facilities, main pipelines, engineering and communication networks, irrigation and melioration systems of Republican and local importance);

* Execution of approved general plans of population sites in the part of construction of objects on account of funds of the state budget of the Republic of Uzbekistan;
* Implementation of projects envisaging the construction of state educational, medical, cultural and social protection institutions established in state investment programs from the account of centralized investments.

As it is clear, the experience of developed countries in the above law, which is expected to be the main normative-legal document aimed at regulating relations, is also taken into account. We can also look through it below.

The legislation of some states on the concept of state and public need has guided the following::

- For Transport purposes - roads, bridges, canals, highways, ports, airports, etc.;

- Public buildings - schools, libraries, hospitals, factories, religious institutions, communal houses;

* Utilities-water (water), sewerage, electricity, gas, communication, irrigation, drainage, reservoirs, dump;

- Public villains, playgrounds, gardens, sports facilities, cemeteries;

* Defensive goals[5].

Whereas, some states do not consider to give any definition to the concept of public and public interests in the legislation. Both cases have their own advantages and disadvantages. If the concept of state and public needs, like the first group of states, is given a clear definition in the law, then it will have partially limited powers in the matter of compulsory abolition of the right to property, that is, unless a certain type of public need can not be recognized as a state and public need. Therefore, giving a clear definition to this concept in the law can narrow its content. 
However, if this is viewed from the point of view of the owners, in this case it will be possible to observe that their interests will be protected for a while. And this is a positive aspect of giving a clear definition to this concept. The negative aspect of not describing these concepts is that the the owner's interests can be humiliated, and representatives of the authorities can commit various abuses. Also, in the event of a dispute in this case, it may be difficult for the courts to resolve the dispute for a while.

In the Republic of China, the cases of the seizure of property without public interest are very much tripled. Although Chinese law dictates that lands intended for agricultural purposes can be seized only by the interests of the public, the concept of "public interest" in national law is not described at all. According to Chinese legislation, it is established that rural lands can only be urbanized after the seizure by the state. Thanks to this, the owners of agricultural land can not sell their land to urban investors at their discretion. As a result of this, the practice of forced seizure by the state in the suburbs of China is very common. Ultimately, the Chinese government is forced to reconsider the norm of law related to public needs[6].

The legislation of some states has developed the legal framework for clearly defining the scope of state and public needs. For example, according to Kenyan state law, in order to confiscate property for the needs of the state and the public, it must first be proved with clear evidence of what benefit it has to the public from the seizure of this property. The lack of such facts hinders the seizure of property[7].
The main purpose of such practice is to eliminate cases of unreasonable seizure of property belonging to citizens. Therefore some state governments bring back such unreasonably occupied land and property to its owner for the purpose of restoring the violated rights.

The seizure of the land plot for the needs of the state and the public is different from that of the Western countries in the practice of Uzbekistan. Since, in the legislation of many Western countries, the right to private property in relation to land is introduced. And this means that in Western countries, the practice of property seizure for the needs of the state and the public will focus on two properties at the same time - on the land and on the real estate located on it (housing, apartments, buildings).

We will touch upon the seizure of the land plot for the state and public needs on the example of Germany. This social relationship in Germany consists mainly of two major stages:

1. Prove that the seizure of the land plot has a legal basis;

2. Determine the amount of specific compensation.

The main participants in the seizure process are the plaintiff (takeover), the owner of the land plot, the local state authorities, the Highresident body with the authority to seizure , the appraising Committee and, eventually, the court. The withdrawal process is considered to have started from the time the claimant has submitted the application. The application is initially submitted to the local government authority, while the local government 
authority submits to the seizure authority with the addition of its statement of claim.

The initial contract of the withdrawal phase is considered very important. The seizure body checks the prerequisites and submits an assessment to the appropriate commission. Property valuation is carried out by appraisers who are responsible for the territory or by experienced appraisers.

Official information about the withdrawal is rare and we provide one of them. The agreement of the parties was signed before the start of the official process of seizure of $80 \%$ of the land plot carried out in the German city of Myunster.

The official process of withdrawal is considered to have begun when the parties are called for a judicial process or hearing. The fact that the application for withdrawal in accordance with the legislation is not submitted, but the fact that the parties are called to hear, is accepted as the beginning of the withdrawal, indicates how important the hearing stage is. At this stage of the moment the relationship takes a mass touch. Because at this stage, the beginning of the process will be published in local publications and recorded in the land register.

The most important part of the process is the compensation phase. Because assessment and compensation must maintain a balance between the right holder, that is, the material condition of the landowner and the degree of importance of the public need, as well as its impact on the economy. If the amount of compensation is less than the Real value of the property being transferred, it will be assessed as injustice at the country level. The fact that the amount of compensation above the property in other respects is not supported as a public need causes this relationship to fail.

According to German law, compensation should include:

The market value of the property-the market value of the property;

Other damages incurred as a result of the put;

It is also necessary to provide for an increase in the price of the property under consideration.

There are also the following types of compensation:
$\checkmark$ As a monetary form;
$\checkmark$ In the form of property;
$\checkmark$ By granting other rights[8].

In conclusion, the seizure of the land plot for the needs of the state and the public is carried out in Germany in a similar way to our national legislation. Alternatively, there are aspects that we can introduce into our national legislation and these are as follows:

A special body engaged in the seizure of land for the needs of the state and the public should be established and this body should be professionally engaged in this regard;

$\checkmark$ Misappropriation of appraisals made by a specially authorized body;

We should also pay attention to the fact that in addition to the specially authorized bodies of appraisers, there are also professional specialized appraisal organizations, the list of 
which stands in the permanent list of Chambers of Commerce and Industry. In addition, in many developed countries, evaluating organizations take into account the same market value of goods in the process. The current practice shows that in our country, when the land plot is seized for the needs of the state and the public, a lot of disputes related to the appraisal of the same are frequent. In order to overcome these problems, it is worthwhile to improve our national legislation by studying how the same attitude is regulated in the legislation of developed countries.

\section{REFERENCES}

1. Compulsory acquisition of land and compensation. FAO LAND TENURE STUDIES.: FOOD AND AGRICULTURE ORGANIZATION OF THE UNITED NATIONS Rome 2008. $\mathrm{p} 5$.

2. https://www.homeloanexperts.com.a u/home-loan-articles/compulsoryacquisition/Ўзбекистон Республикаси Фуқаролик кодексига шарх. 1-жилд (биринчи қисм) Адлия вазирлиги. -Т.: «Vektor-Press», 2010. - 816 б. (Профессионал (малакали) шархлар).

3. https://regulation.gov.uz/uz/d/42584,

4. PPP in Infrastructure Resource Center for Contracts, Laws and Regulation (PPPIRC). Vol.3 www.worldbank.org/ppp,

5. PPP in Infrastructure Resource Center for Contracts, Laws and Regulation (PPPIRC). Vol.3 www.worldbank.org/ppp.

6. http://land.igad.int/index.php/docume nts-1/countries/kenya/investment- 3/648-land-for-infrastructuredevelopment-compulsory-acquisitionand-compensation-of-unregistreredland-inkenya/file\#: :text=In\%20the\%20Kenyan $\% 20$ Constitution\%2C\%20Article,a\%20titl e\%20to\%20the\%2oland.

7. Миллий қонунчилигиздан фарқли ўлароқ Германияда ер участкасини олиб қўйиш билан шуғулланувчи махсус орган хам мавжуд.

8. http://www.fig.net/pub/fig2010/papers /ts03f/ts03f_voss_4220.pdf (Compulsory Purchase in Poland, Norway and Germany - Part Germany). 